\title{
THE MARKETING ROLE IN IMPROVING THE COMPETITIVENESS OF THE REGION
}

\author{
Yuliia SHAPOVAL' \\ Cherkasy State Technological University, Ukraine
}

\begin{abstract}
The research objective is the sight of theoretical aspects formulation and prediction of competitiveness of regions within the framework of modern marketing positions. The evolution, programs, strategies, and factors of marketing are analysed, which affects the attractiveness of the regions. Methodology. In the study process, a combination of the following methods is used: generalization and scientific abstraction to specify the key definitions and categories, monographic method - for presenting the opinion of scientists regarding the directions of application of marketing tools in the process of managing the competitiveness of regions, comparative analysis - to detect features of application programs and marketing strategies. Results. It is considered that regional marketing is a mechanism that provides a methodology and tools for ensuring the competitiveness of the territory. It allows determining the marketing type of territorial management, which is formed not from the wishes of the authorities (for example, in search for funds for the implementation of certain projects), but from the study of the needs of consumers (entrepreneurs, local residents, investors, tourists), which the territory has the opportunity to satisfy; analyse the market opportunities and determine the competitive advantages of the territory, as well as influence the sustainable economic growth. It is determined that the competitiveness of the region is defined as a potential opportunity to win in a competition between territories for the benefits that satisfy needs and are distributed among the population and business entities that identify themselves with the region, as well as visitors who have certain intentions in this region. In fact, we are talking about the choice of priorities, in which this territory has competitive advantages, the raise of which can lead to heightening living standards, which is an indicator of the competitiveness of the region. The practical implication. According to the concept of marketing, goals of the region, especially long-term, can only be achieved through the study of the consumer demand, therefore, it requires: to study not the production capacity but market needs and develop plans for their fulfilment; bind the goals and resources of the region; evaluate external influences on the territory; focus on the long term.
\end{abstract}

Key words: regional marketing, competitiveness, branding, image of region.

JEL Classification: M00, M31, V39

\section{Introduction}

In the context of Ukraine's European integration intentions, growing globalization, and geo-economic competition, the problem of creating an adequate mechanism for planning the development of its regions, as administrative and territorial units of the state, is becoming more and more actualized.

Priority directions for reforming the sphere of regional development became: the introduction of an integrated approach to solving problems in order to achieve sustainable development and increase the competitiveness of the economy of the regions; borrowing the best tools strengthening regional development, developed in the countries of the European Union. Nowadays, it is implementing change bureaucratic management technologies for the client-oriented development of modern European mechanisms of local self-government on the principles of demonopolization of the economy and improvement of the competitive environment.

Regions today face the need to conduct an independent social and economic policy. That is why there is pointed an issue of the formation of an effective regional policy aimed at reforming the economy and, as a consequence, investment attraction. Clearly developed and implemented the development of territories based not so much on centralized financial resources but the use and development of local capacity should be based on new market mechanisms of cooperation between different departments.

\footnotetext{
Corresponding author:

${ }^{1}$ Department of Economic Cybernetics and Marketing, Cherkasy State Technological University.

E-mail: bonta89@ukr.net
} 


\section{Literary review and the formation of article objectives}

Determining the role of marketing in ensuring the competitiveness of country, region, and city was reflected in the scientific works of many foreign and domestic scholars, and all of them, of course, have a great theoretical and practical value, but declared developmental problems are so complicated and diverse that there are no unitary recipes for the formation of a competitive advantages. Each territory forms them independently, which confirms the nature of various types of territorial marketing, which have been formed from practices provoked by the competition of territories and the growing role of local government (Starostina, 2004). Focus on the meaning of territorial marketing in the development of countries, regions, cities, and the transformation of the regional markets system is made by J. Bitner and B. Booms (Bitner, 1992), L. Budd (Budd, 1998), A. Szomnik (Szomnik,2008), I. Gordon and P. Cheshire (Gordon, Cheshire, 1998), T. Karpova (Karpova), I. Bunyak (Bunyak, 2006), Yu. Makogon and V. Biletskyi (Makogon, Biletskyi, 1998), and others. It is important to show that nowadays the main role plays innovative investment directions of increasing the competitiveness of regions.

The purpose of the article is to determine the role of regional marketing by studying the directions of its implementation as a tool for increasing the competitiveness and investment attractiveness of the region.

\section{Presentation of the main material}

The modern region needs to be considered as a clearly defined political, social, institutional, and oriented space that has a dual nature.

On the one hand, it is a multidimensional structure that combines various sub-systems, based on the interaction of natural, technological, and social processes that occur simultaneously, as well as economic, demographic, environmental, cultural, and political factors. On the other hand, the region is a link of the spatial structure of the economy, that is, the special type of economic systems that arise from development, based on interconnected production population and resource areas that allows the region to act as an independent subject of economic development. Marketing of the region according to modern approaches can be defined as a way of establishing, creating, maintaining such relations with different market players that would provide the favourable position of the region concerning resources and target markets, and also allowed to meet the objectives of participants in these relations. Thus, marketing of the region is aimed at detecting needs of counterparties region, coordination of these interests with the interests of the region, and achievement on this basis of competitive success and social-economic goals.
Marketing as a managerial reality undoubtedly evolves and, in this process, you can already find certain stages. In this context, the development of views of Ph. Kotler (Kotler, 2000), a universally recognized authority in this field of knowledge is shown. Analysing the evolution of views of the role of marketing, he highlights the following stages:

1) Marketing becomes a function equivalent to production management, finances, personnel.

2) The role of marketing in comparison with the listed functions is increasing.

3) Marketing is transformed into a basic function, which has subordinated others.

4) The consumer becomes a control point for the progress of listed functions.

5) Consumer actions act as controlling, and marketingas an integrator function.

There are different approaches to the regional marketing function. Thus, a part of the scholars emphasizes the marketing of regions to determine the characteristics of regions with using marketing tools, in particular, advertising, sponsorship, in order to enhance the image of the region, its place in the country and abroad (Pankrukhin, 2006). In order to imagine the marketing of the region as a complete system, it is necessary to highlight principles of marketing of the region, subjects, objects, goals, elements, methods, the composition of the marketing program (Fig. 1).

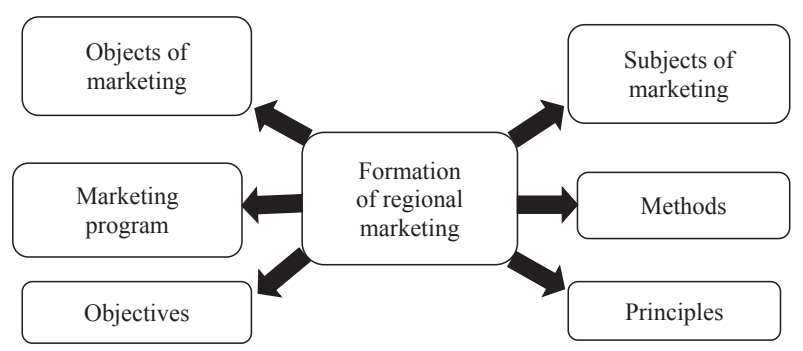

Fig. 1. Formation of regional marketing management system

Source: Developed by the author

Regional marketing is a mechanism that provides a methodology and tools for ensuring the competitiveness of the territory. It allows you to determine the marketing type of territorial management, which is formed not from the desires of power structures (for example, in search for money funds for the implementation of certain projects) but from the study of the consumers demands (entrepreneurs, locals, investors, tourists) that the territory has an opportunity to gratify; analyse market opportunities and detect the competitive advantages of the territory, and also affect the provision of sustainable economic growth.

Territory marketing is one of the strategic factors, as it is able to have a long-term impact on its economic development. Territory marketing is a factor, on the one hand, and on the other - a mechanism for ensuring competitiveness. Marketing of the region helps to carry 
out a structural analysis of the region's economy in order to determine the effectiveness of the specialization of the region, possibilities of restructuring the economy in the presence of new competitive advantages.

Regional marketing programs are formed on the basis of the following principles:

- promotion of the region as a place for various projects, based on knowledge and forecasting of the needs of the economy, the current situation and opportunities of the region;

- an effective solution to the problems of the region's economy;

- focus on long-term sustainable development;

- influence on the formation of needs and behaviour of subjects on investment market.

The purpose of regional marketing is the effective use of existing ones, as well as the creation of new benefits for attracting to the regional economic agents able to increase the well-being of its inhabitants.

Among the programs promoting the region are branding - activities to create long-term benefits for the product, based on the active and emotional impact on the consumer of the trademark, including advertising that allocates goods (in this case, the region) among competitors and creates its positive image (brand), and the formation of the image of the region. Marketing and branding of territories do not have one pattern. Depending on the specifics of the region and the set of tasks, the structure and composition of the program promotion can be different.

In fact, the entire process of forming regional marketing is divided into two blocks: the positioning of the region and its promotion program.

The main factors that influence the attractiveness of a particular region, one area or another for investors and the population are as follows:

1. Real level of development and prosperity of the region - when choosing a region as population and investors usually take into consideration: the level of urbanization of the territory; migration situation, opportunities for labour and social mobility of people; demographic situation; functioning of the housing market; regional problems of development of education, healthcare, transport infrastructure, and some others.

2. The image of the territory - a combination of emotional and rational representations arising from the comparison of all signs of the territory, own experience of people and rumours that affect the creation of a certain image. Empirical research shows that there are following directions of marketing policy in the field of improvement image of territory:

1) realization of its three main functions - place of residence, recreation places, and places of management; 2 ) improvement of the management and infrastructure of the territory;

3) increasing the competitiveness of enterprises located in the region. In this case, image marketing traditionally concentrates efforts on improving communicative aspects, information and advocacy of the previously created advantages of the territory.

3. Reputation - a dynamic characteristic of the life and activity of the territory, formed during a long period of time from the aggregate of reliable information about it. This information is firstly included on the comfort of living on the territory, security, social security, the authority of regional authorities, etc. In addition, the reputation of the territory is determined and its emotional attractiveness, for example, the presence of the seaside or historical memorials; The reputation of the region's leadership in terms of efficiency and honesty of the execution of investment vouchers; financial and economic indicators of the regional development; investment activity in its territory. Exactly the reputation of the region, territory, city, as international experience shows, serves the most important factor in its investment attractiveness. Today the following basic strategies of territorial marketing are used.

Image marketing. The purpose of this strategy is to create and distribute, for example, potential investors or tourists a positive image of the territory. The leading image marketing tool is communication activities that demonstrate the openness of the area for contacts and open up wide opportunities for the acquaintance with it.

Marketing attractiveness - aimed at increasing the attractiveness of the territory - the most diverse (from competitive advantages to investors to the presence of attractions and entertainment for tourists) for human life, business development.

Infrastructure marketing is the most important and, in the long run, the most stabilizing element of marketing in the region since the infrastructure is the foundation of its attractiveness. Often, this means reliable energy supply, clean drinking water, developed communications, good transport connections, and security in the streets of cities. In a number of cases (in particular, during the competition between cities for holding "Eurovision-2017") as the main elements of the infrastructure, first of all, the availability of modern concert halls, airports, hotels, roads were considered.

Marketing of the population, personnel - for the development of the territory, each region can choose its own strategy, which is responsive to its features. So, areas with low employment and cheap labour can put this circumstance to attract investors in order to create new jobs. When implementing this strategy in relation to tourism, it is important to form a benevolent motivation of the local population in relation to tourists and other visitors.

Marketing of attractions, entertainment - this strategy complements marketing image. For its implementation, there are natural monuments (beautiful embankments of rivers, lakes, seas, mountain landscapes), historical heritage (museums, monuments of architecture, temples), interest in the life and work of famous people, 
cultural and recreational facilities (stadiums, cultural and shopping centres, parks).

Currently, the majority of subjects face the problem of improving the image and investment attractiveness of the regions, the allocation of priority directions of development, the creation of effective interregional cooperation programs. Development of programs of regional marketing is a relevant task of economic development of all subjects. Regional marketing creates the basis for the economic activity of regional enterprises, allows the implementation of effective market mechanisms at the macro and microeconomic levels, answers the majority of issues related to the allocation of primary goals and objectives of the region.

A concrete regional marketing tool may be a regional promotion plan. Under the promotion of the territory, one understands, first of all, an advertising campaign.

In terms of promotion of the region, channels of promotion of information, its volume are determined, the level of its influence is monitored, and the necessary changes are made. It should include the following sections: research, economic analysis of the business environment and commercial activity; education; public relations, and advertising.

The plan may be supplemented by sections on the financing of the region and control procedures. It is a system of actions that create and maintain competitive advantages of the region that can be sustained for a long time. This is one of the most effective methods for managing the development of the region (Visionary, 2007).

\section{Conclusions}

Consequently, regional marketing seems to be the most effective economic form of a solution of contradictions between the branch and the regional beginning, between the centre and regions in the management of the modernized economy of Ukraine. A specific tool for regional marketing is the regional promotion plan - an action system that creates and maintains the competitive advantages of the region for a long time. Regional marketing in the regional markets system enables to create the best competitive advantages in favour of customers in comparison with other territories, promotes efficient use of resources for the purpose of the increase in competitiveness and image, promotes attraction of economic agents, increase in attractiveness and competitiveness of the region, aimed at ensuring sustainable development of the region, formation of long-term and mutually beneficial relations with internal and external partners. Accurate and systematic application of marketing tools and technologies will enable the region to: generate additional resources for its functioning and attract the attention of all stakeholders; direct the activities of local authorities to meet the needs of external and internal actors to increase investment attractiveness of the region; to meet the needs of certain target audiences by forming long-term competitive advantages and identifying priority directions of the region's development; to implement the principles of social, ecological and economic responsibility of territorial entities and to ensure sustainable socio-economic development of the region; to form, maintain, and develop mutually beneficial long-term relations with participants in the process of interaction, the purpose of which is to create new values aimed at ensuring sustainable development of the region.

Besides, marketing technologies form the scientific and applied bases for the development of regional strategic development programs, change the stereotypes of thinking of civil servants in order to prioritize the needs of citizens, enterprises, and organizations in the region, allow for flexible response to changes in the environment, reduce uncertainty in the adoption of management decisions, improve the quality of territorial administration, form a new type of management and organizational culture in local authorities in the direction of partnership and interaction with local communities, entrepreneurs, and investors.

\section{References:}

Bitner J., \& Booms B. (1992). Marketing of services, Journal of Marketing. Vol. 56, April. N 2. 57-71 pp. (in Eng.) Budd L. (1998). Territorial Competition and Globalization: Scylla and Charybdis of European Cities L. Budd Urban Studies.Vol. 35, 663-685 pp. (in Eng.)

Bunyak N.M. (2006). Formation of the marketing strategy of the region's development and its realization mechanism: diss. Cand econ Sciences: special 08.10.01. (in Ukr).

Vityanin VI (2007). Regional Economics: Textbook VI Vydianin, MV Stepanov. M.: INFRA, 666 p.(in Ukr).

Gordon I. R. (1998). Locational advantage and the lessons of territorial competition in Europe. Paper prepared for the International Workshop on "Theories of Regional development: Lessons for Policies of Regional Economic Renewal and Growth" I. R. Gordon, P. C. Cheshire., Uddevalla.(in Swed).

Karpova T. Y. City development management: marketing aspect [Electronic resource] T.Yu. Karpova Retrieved from URL: http://www.lib.csu.ru/vch/7/2003_01/016.pdf.

Kotler F. (2000). Fundamentals of Management: Per. from english 2nd ed. F. Kotler, Armstrong G., Saunders J., Wong B., M.: St. Petersburg; K.: Williams Publishing House, 944 p. (in Eng). 
Makogon Y.V., S. Biletskyi (1998). Attracting Foreign Investments to Ukraine (Regional Aspect) Regional Policy of Ukraine: Scientific Foundations, Methods, Mechanism: Sb. sciences works on materials supplementary international science-practice Conf., -Lviv. 262-268 Pp. (in Ukr).

Pankrukhin A.P. (2006). Territory marketing. 2nd ed., Supplemented by A.P .Pankkrutin, St. Petersburg: Peter, p. 416.

Starostina, A.O., \& Martov, S.E. (2004). Regional marketing: content and features in Ukraine, Marketynh v Ukraini, 3, 55-57 pp. (in Ukr).

Szromnik A. (2008). Marketing terytorialny. Miasto i region na rynku A.Szromnik. -Kraków: Oficyna, 184 p. (in Pol.)

\section{ЮЛИЯ ШАПОВАЛ}

\section{РОЛЬ МАРКЕТИНГА В ПОВЫШЕНИИ КОНКУРЕНТОСПОСОБНОСТИ РЕГИОНА}

Аннотация. Целью исследования является рассмотрение теоретических аспектов формирования и повышения конкурентоспособности регионов в рамках современных позиций маркетинга. Проанализирована эволюция, программы, стратегии и факторы маркетинга, влияющие на привлекательность регионов. Методология. В процессе исследования были использованы комбинации следующих методов: обобщение и научной абстракции для конкретизации ключевых определений и категорий, монографический метод - для представления мнения ученых относительно направлений применения маркетинговых инструментов в процессе управления конкурентоспособностью регионов, сравнительный анализ - для выявления особенностей применения программ и стратегий маркетинга. Результаты. Рассмотрено, что региональный маркетинг является механизмом, который предоставляет методологию и инструментарий для обеспечения конкурентоспособности территории. Он позволяет определить маркетинговый тип территориального менеджмента, формируется не от желаний властных структур (например, в поиске денежных средств для реализации определенных проектов), а от изучения потребностей потребителей (предпринимателей, местных жителей, инвесторов, туристов), которые территория имеет возможность удовлетворить; провести анализ рыночных возможностей и определить конкурентные преимущества территории, а также влиять на обеспечение устойчивого экономического роста. Установили, что конкурентоспособность региона определяется, как потенциальная возможность побеждать в условном соревновании между территориями за блага, которые удовлетворяют потребности и распределяются между населением и субъектами хозяйственной деятельности, которые идентифицируют себя с регионом, а также приезжими, имеющих определенные намерения в данном регионе. Фактически, речь идет о выборе приоритетов, в которых данная территория имеет конкурентные преимущества, усиление которых может привести к повышению жизненного уровня населения, что является индикатором конкурентоспособности региона. Практическое значение. Согласно концепции маркетинга, цели региона, особенно долгосрочные, могут быть достигнуты только путем изучения потребительского спроса, поэтому она обязывает: изучать не производственные мощности, а потребности рынка и разрабатывать планы их удовлетворения; связывать цели и ресурсные возможности региона; оценивать внешние воздействия на территорию; ориентироваться на долгосрочную перспективу. 